\title{
PENGGUNAAN TENAGA PROFESIONAL DALAM IKLAN PRODUK BARANG DAN JASA KAITANNYA DENGAN PERLINDUNGAN KONSUMEN
}

\author{
Ratna Widayati \\ Akademi Keuangan dan Perbankan Padang \\ ratnawidayati@akbpstie.ac.id
}

\begin{abstract}
Advertising is one form of marketing products and services which are very well known in the community. But so many forms of advertising that actually banned, just a lot shown on television. As the use of physicians, health professionals, or the actor who plays a doctor or health worker in drug advertising. Doctors use the drug ads will only mislead the public as consumers, because doctors are more competent when it comes to drug problems. Directly with the public will believe that drugs advertised although there is no guarantee they can cure. Furthermore it will cause unfair competition among the manufacturers of drugs, because every manufacturer will race to put on doctors or the actor who played the doctor to advertise their drug products. Thus the independence of physicians as if mortgaged or disadvantaged by side with a particular product or brand, while also able to mislead the public as users / consumers of the product.
\end{abstract}

\section{PENDAHULUAN}

Didalam dunia bisnis, khususnya perdagangan pada dasarnya konsumen tidak akan mengetahui semua jenis produk barang dan jasa apa saja yang ada di pasaran. Untuk menyampaikan informasi produk barang dan jasa apa saja yang ada di pasaran tersebut digunakan iklan, baik melalui media cetak maupun media elektronik, dimana iklan bagi pelaku usaha adalah media yang sangat dibutuhkan untuk memasarkan produknya dan menaikkan jumlah penjualan, dan iklan merupakan persuasi yang ditujukan kepada sekelompok masyarakat agar menjatuhkan pilihannya kepada merek tertentu (Simatupang Taufik H;2004). Karena itu sangat berhubungan erat dengan pemasaran penjualan sebuah merek, dimana diharapkan dari iklan tersebut, semua konsumen akan menjatuhkan pilihannya pada produk atau merek barang dan jasa yang diiklankan.

Jika melihat perkembangan dunia periklanan sekarang ini sangat luar biasa. Banyak sekali tampilan iklan, baik di media elektronik maupun media cetak yang penuh dengan kreatifitas dan memiliki nilai seni yang tinggi, yang begitu sensasional, dan tidak jarang menembus batas rasional. Daya pikat psikologis dan 
sentimen-sentimen konsumtif menjadi sasaran utama sebagian besar pelaku usaha periklanan.

Sebagai ujung tombak kominikasi pemasaran, iklan mempunyai peran yang sangat penting. Oleh karena itu, dalam menarik simpati publik agar mengesankan iklan itu sebagai suatu yang baru dan unik sebagai tayangan yang melekat dalam pikiran masyarakat, maka iklan dirancang dalam sebuah kemasan yang sesempurna mungkin. Namun teori dan praktek di lapangan selalu kita saksikan berbeda secara normatif, yaitu pesan yang disampaikan di luar aturan yang telah digariskan, baik yang diatur dalam Undang-undang, Peraturan Pemerintah ataupun Tata Krama Asosiasi Profesi(Simatupang Taufik H;2004)

Jika dicermati lebih lanjut, masih banyak iklan-iklan yang melanggar Tata Krama dan Tata Cara Periklanan Indonesia, baik yang disengaja maupun tidak disengaja. Contohnya saja masih banyak iklan obat yang menggunakan tenaga profesi kesehatan ditambah dengan mengeksploitasi sisi ketakutan masyarakat dengan mengangkat suatu penyakit dan dan menghubungkannya dengan obat atau suplemen sebagai obat dari penyakit dengan kata lain jika tidak mengkonsumsi produk (obat atau suplemen) tersebut (yang di iklankan) akan menimbulkan suatu penyakit. Hal ini diambil sebagai jalan pintas untuk menaikkan angka penjualan produk yang di iklankan. Hal tersebut merupakan pelanggaran terhadap aturan-aturan yang berlaku seperti Tata Krama dan Tata Cara Periklanan Indonesia (TKCPI) yang merupakan Kode Etik Pariwara Indonesia, ataupun aturan lain yang terkait dengan periklanan. Hal ini menandakan adanya pergulatan antara etika di satu pihak dan kepentingan bisnis di pihak lain. Kondisi ini sebagian besar terjadi akibat masih awamnya para pelaku periklanan maupun masyarakat sendiri dalam etika beriklan

Secara formal, aturan periklanan obat khususnya di Indonesia melarang penggunaan identitas profesi tertentu yang berkaitan dengan produk yang diiklankan,karena hal tersebut membuat konsumen percaya langsung bahwa produk itu suatu benar-benar teruji secara medis dan dapat pula dipertanggungjawabkan secara professional. Misalnya saja, menampilkan tokoh dokter di iklan produk obat atau produk kesehatan lainnya. Ini merupkan aturan yang paling sering dilanggar oleh pihak pengiklan. Padahal sudah jelas diatur pada Etika Tata Krama dan Tata Cara Periklanan Indonesia pada Bab II C No.2. Tidak hanya itu, hal di atas juga dilarang di dalam SK Menteri Kesehatan No. 368 bagian a No.9 yang mengatur mengenai Pedoman Periklanan Obat Bebas, Obat Tradisional, Kosmetika, Perbekalan Rumah Tangga dan Makanan-Minuman.

Apabila dilihat dalam kenyataannya, para praktisi iklan ini masih saja tidak ingin terikat dengan etika periklanan yang berlaku bahkan mereka terus berdalih dan berlindung di balik argument bahwa sosok yang ditampilkan dalam iklan (yang dikesankan sebagai dokter) itu adalah orang biasa yang berpakaian putih. Perkara penonton mempersepsikan sebagai dokter, itu adalah urusan mereka sendiri. Padahal pakaian yang berjas putih itu menerangkan hal-hal yang berbau medis, apalagi ditambah setting ruangan yang dibuat menyerupai laboratorium yang di isi oleh alatalat kedokteran atau medis (teleskop, gelas ukur, tabung kimia, dll). Lagi pula pada 
umumnya yang menggunakan jas putih adalah dokter, setidaknya itulah opini masyarakat.

Kasus di atas merupakan sisi negatif dari fenomena periklanan khususnya di Indonesia. Padahal di tengah kebanggaan terhadap karya-karya anak bangsa yang telah mengangkat citra periklanan di Indonesia, hal-hal yang menyimpang dari aturan yang telah mengangkat citra periklanan di Indonesia, hal-hal yang menyimpang dari aturan yang nantinya menjadi rapor merah periklanan, tidak lagi ditemukan. Untuk itu perlu kesadaran semua pihak agar sama-sama menyadari dan mematuhi aturan yang berlaku. Baik dari pengiklan, agar tidak memaksakan kehendaknya pada perusahaan periklanan mereka untuk melanggar etika. Juga dalam mematuhi etika pariwara seperti menghormati kontrak yang telah disepakati dengan perusahaan periklanan mereka (Simatupang Taufik H;2004)

\section{Pengaturan Tentang Penggunaan Tenaga Profesi Kesehatan Dalam Periklanan}

Sebagai sebuah karya iklan bisa memperkaya khasanah budaya. Sebagai alat pemasaran, iklan merupakan salah satu syarat penting untuk pertumbuhan daya jual barang atau jasa yang ingin ditawarkan pada konsumen. Iklan harus mampu menumbuhkan daya tarik, rasa membutuhkan, dan rasa ingin membeli atau memiliki barang yang diiklankan, dan semua itu harus ditumbuhkan iklan melalui informasi yang disuguhkan iklan tersebut. Dengan demikian secara kondisional selain berfungsi meberikan pemahaman tentang keberadaan produk, iklan sekaligus mejadi mediasi dalam membujuk konsumen untuk secara sukarela mencoba atau membeli produk yang ditawarkan. Iklan tidak hanya sebagai sebuah media pemasaran, tetapi juga mempengaruhi sikap, tingkah laku, dan pola pikir masyarakat sebagai konsumennya . Maka dari itu, dibuat sebuah aturan tentang Tata cara dan tata Krama Periklanan Indonesi, yang tujuannya adalah :

- Melindungi usaha periklanan pada khusunya, dan industri komunikasi penasaran pada umumnya, serta pada gilirannya juga kepentingan masyarakat secara keseluruhan.

- Menegakkan kewibawaan usaha periklanan, asosiasi dan segenap anggotanya.untuk terwujudnya fokus persaingan di dalam peningkatan kualitas, sekaligus untuk memantapkan segala jenis layanan anggota kepada para kliennya.

Perusahaan periklanan sebagai usaha yang bergerak dibidang jasa memperoleh izin usahanya dari Depertemen Perdagangan dan koperasi. Dalam iklan produk obat iklan harus mendapat persetujuan dari Direktorat jendral Pengawas Obat dan Makanan atau POM. Periklanan merupakan usaha jasa yang di satu pihak menghubungkan perodusen barang dan jasa dengan konsumen, dan di lain pihak menghubungkan pencetus gagasan dengan penerima gagasan. Dalam hubungan ini kecuali mengandung unsur pemasaran barang dan jasa, periklanan juga mengandung unsur komunikasi yang idiil. Dilihat dari Undang-Undang perlindungan konsumen Pasal 1 ayat (6) dijelaskan bahwa promosi adalah kegiatan pengenalan atau penyebar luasan informasi suatu barang atau jasa untuk menarik minat konsumen terhadap barang dan jasa yang akan dan sedang dipergunakan. Sedangkan pengertian iklan 
sendiri menurut Undang-Undang Periklanan adalah segala bentuk pesan tentang suatu produk yang disampaikan melalui suatu media dibiayai oleh pemrakarsa yang dikenal, serta ditujukan kepada sebagian atau seluruh masyarakat.

Perikanan tidak boleh bertentangan dengan segala peraturan perundangan yang berlaku hal ini telah diatur dalam Tata Krama Periklanan Indonesia Bab II Penerapan Umum point I huruf d yang berbunyi : "iklan harus mematuhi segala peraturan yang berlaku".

Peraturan tersebut tentunya sangat terkait dengan pelaku periklanan. Isi dari suatu iklan pun harus menyatakan kebenaran atas pernyataan atau janji dari sebuah produk yang harus dapat dipertanggungjawabkan.

Penampilan tenaga professional seperti dokter,ahli farmasi, tenaga medis dan para medis lain atau atribut-atribut profesinya tidak boleh digunkan untuk mengiklankan produk obat-obatan, alat-alat kesehatan maupun kosmetika. Sebab segala tindakan yang dilakukan oleh tenaga profesi harus dapat dipertanggungjawabkan secara kode etik dari profesi tersebut. Para tenaga profesi harus berada di wilayah yang tidak memihak, apalagi memerankan sebuah iklan untuk sebuah produk. Hal ini akan merusak eksistensi dari sebuah profesi.

Kode Etik Kedoteran. Pada bagian kewajiban umum, Pasal 3 KODEKI (Kode Etik Kedokteran) menyebutkan, dalam melakukan perkerjaan kedokterannya, seorang dokter tidak boleh dipengaruhi, oleh sesuatu yang mengakibatkan hilangnya kebebasan dan kemandirian profesi. Aturan perikalanan di Indonesia juga melarang mengunakan identitas profesi tertentu berkaitan dengan produk yang diiklankan. Produk obat berkaitan dengan profesi kedokteran, jika suatu produk obat-obatan, alat kesehatan maupun kosmetika diiklankan oleh tenaga profesi kesehatan seperti dokter secara otomatis membuat konsumen akan percaya dan menganggap produk obat tersebut adalah rekomendasi dari dokter dan telah teruji secara medis dapat dipertanggungjawabkan secara professional.

Maka dari itu beberapa peraturan baik peraturan tentang periklanan maupun aturan tentang kedokteran melarang seorang tenaga profesi kesehatan atau dokter untuk mengiklankan atau menjadi aktor dalam sebuah iklan obat-obatan, alat kesehatan maupun kosmetika. Berikut adalah aturan yang melarang pengunaan tenaga profesi kesehatan atau dokter memerankan atau menjadi seorang aktor dalam iklan obat, alat kesehatan dan suplemen.

\section{a. Surat Keputusan Menteri Kesehatan}

Pada SK Menteri Kesehatan no.368 tentang perikalanan obat bebas, obat tradisional, kosmetika, perbekalan rumah tangga dan makan-minuman bagian a no.9 dijelaskan bahwa" Iklan obat tidak boleh diperankan oleh tenaga profesi kesehatan atau aktor yang berperan sebagai profesi kesehatan dan atau menggunakan "setting" yang beratribut profesi kesehatan dan laboratorium"

Seperti dijelaskan diatas tenaga kesehatan maupun berbagai settingan yang mengiring opini masyarakat atau berkonotasi tenaga profesi kesehatan tidak boleh digunakan dalam iklan obat.

b. Peraturan Pemerintah No.26 Tahun 1960 
Sebagai sebuah profesi yang menyangkut hidup masyarakat maka seoarang sarjana kedokteran sebelum diangkat sebagai dokter yang baru maka ia harus terlebih dahulu melafalkan sumpah dokter Indonesia yang berbunyi :

"Demi Allah saya bersumpah/berjanji, bahwa :

i. Saya akan membaktikan hidup saya guna kepentingan perikemanusiaan

ii. Saya akan memelihara dengan sekuat tenaga martabat dan tradisi luhur jabatan kedokteran ;

iii. Saya akan menjalankan tugas saya dengan cara yang terhormat dan bersusila, sesuai dengan martabat pekerjaan saya sebagi dokter ;

iv. Saya akan menjalankan tugas saya dengan mengutamakan kepentingan masyarakat

v. Saya akan merahasiakan segala sesuatu yang saya ketahui karena pekerjaan saya dan keilmuan saya sebagi dokter ;

vi. Saya akan tidak mempergunakan pengetahuan kedokteran saya untuk sesuatu yang bertentangan dengan perikemanusiaan, sekali-pun diancam

vii. Saya akan senantiasa mengutamakan kesehatan penderita ;

viii. Saya akan berikthtiar dengan sungguh-sungguh supaya saya tidak terpengaruh oleh pertimbangan keagamaan, kesukuan, perbedaan kelamin, politik kepartaian, atau kedudukan sosial dalam menunaikan kewajiban terhadap penderita ;

ix. Saya akan menghormati setiap hidup insani mulai dari saat pembuahan ;

x. Saya akan memberikan kepada guru-guru dan bekas guru-guru saya penghormatan dan pernyataan terimakasih yang selayaknya ;

xi. Saya akan memperlakukan teman sejawat saya sebagimana saya sendiri ingin diperlukan ;

xii. Saya akan menaati dan mengamalkan Kode Etik Kedokteran Indonesia ;

xiii. Saya ikrarkan sumpah ini dengan sungguh-sungguh dan dengan mempertaruhkan kehormatan diri saya.

Sehubungan dengan seorang dokter memerankan sebuah iklan obat di televisi jelas hal tersebut melanggar Kode Etik Kedoteran. Pada bagian kewajiban umum, Pasal 3 KODEKI (Kode Etik Kedokteran) disebutkan, dalam melakukan pekerjaan kedokterannya, seorang dokter tidak boleh dipengaruhi, oleh sesuatu yang mengakibatkan hilangnya kebebasan dan kemandirian profesi. Pada penjelasan Pasal 3 Kode etik Kedokteran disebutkan, perbuatan berikut dipandang bertentangan dengan etika :

Membuat ikatan atau menerima imbalan dari perusahaan farmasi/ obat, perusahaan alat kesehatan/kedokteran atau badan lain yang dapat mempengaruhi pekerjaan dokter; melibatkan diri secara langsung atau tidak langsung untuk mempromosikan obat, alat atau bahan lain guna kepentingan dan keuntungan pribadi dokter. c. Undang-Undang No. 8 Tahun 1999 Tentang Perlindungan Konsumen.

Pada Undang-Undang Perlindungan Kondumen memang tidak disebutkan dengan jelas tentang larangan penggunaan tenaga kesehatan dokter dalam iklan Obat 
dan suplemen. Namun Pasal 17 Ayat (1) Undang-Undang Perlindungan Konsumen mengatur tentang larangan bagi pelaku usaha untuk memproduksi iklan dengan kriteria tertentu. Huruf $\mathrm{f}$ dari pasal ini menyatakan kriteria itu mencakup larangan memproduksi iklan yang melanggar etika dan/atau ketentuan peraturan perundangundangan mengenai periklanan (Sidharta;2004). Dihubungkan dengan Etika Pariwara Indonesia bahwa pemakaian tenaga dokter dalam iklan obat merupakan pelanggaran terhadap Bab III point A Tentang isi iklan No. 2.3 Etika Pariwara Indonesia.

Selain dua undang-Undang diatas juga terdapat aturan lain yang disebut Etika Pariwara Indonesia. Yaitu peraturan ayng dibuat dan disepakati oleh perusahaanperusahaan periklanan yang tergabung dalam PPPI (Persatuan Perusahaan Periklanan Indonesia)

Dijelaskan pada Etika Pariwara Indonesia Bab III point A Tentang isi iklan No. 2.3 yang berbunyi "iklan tidak boleh menggambarkan atau menimbulkan kesan pemberian anjuran, rekomendasi, atau keterangan tentang penggunaan obat tertentu oleh profesi kesehatan seperti dokter, perawat, farmasis, laboratoris, dan pihak-pihak yang mewakili profesi kesehatan, beserta segala atribut, maupun yang berkonotasi profesi kesehatan". Berkonotasi profesi kesehatan berarti penggunaan atribut dan seting yang menggambarkan tenaga profesi kesehatan. Seperti penggunaan jas putih yang berkonotasi dokter, ruangan yang di isi dengan mikroskop, gelas kimia, gelas ukur dan atribut - atribut kesehatan lainnya berkonotasi sebagai laboratorium.

\section{Bentuk Tanggung jawab Terhadap Penggunaan Tenaga Dokter Dalam Iklan Obat}

Berbicara menganai iklan tidak hanya berbicara tentang pesan tekstual yang disampaikan produsen kepada konsumen tetapi ada nilai eksplisit dari iklan yang hanya bisa diterima oleh konsumen melalui sebuah peragaan peran atau scenario cerita dan iklan bentuk ini biasanya ada ditelevisi. Hal ini tidak bisa dilakukan media lain seperti radio, koran, majalah, ataupun papan iklan. Maka dari itu tidak heran bila banyak perusahaan yang menghabiskan biaya terbesar iklan untuk beriklan ditelevisi.

Selain itu televisi juga dapat menjangkau masyarakat lebih luas sehingga iklan menjadi lebih efektif. Keuntungan ini banyak dimanfaatkan oleh perusahaan menghegemoni (Piliang YA;2004) masyarakat melalui iklan. Dan Melalui iklan juga diupayakan agar pemuasan kebutuhan konsumen dapat terpenuhi. Mutu pemuasan tersebut berupa semacam "janji" dari pemasang iklan berkaitan dengan objek iklan yang menjadi daya tarik atau daya pikat dalam penyajian pesan iklan produk yang bersangkutan. Maka dari itu dirancanglah sebuah iklan yang diperankan oleh seorang, kelompok, atau badan yang lebih berkompeten dalam suatu produk, agar "janji” yang ditawarkan mudah dipercayai oleh masyarakat.

Dokter adalah seorang yang ber-kompeten ketika berbicara penyakit dan obat, oleh karena itu ketika dokter ataupun sosok dokter dengan ruangan layaknya laboratorium mengiklankan suatu produk obat dan menyarankan kepada masyarakat untuk mengkonsumsi obat tersebut maka akan menimbulkan kesan "wajib" bagi masyarakat. Dengan alasan inilah produsen menjadikan dokter sebagai aktor dalam sebuah iklan obat. Hal ini menimbulkan sebuah persaingan yang tidak sehat di antara 
produsen obat, namun penggunaan tenaga dokter pada sebuah iklan obat di televisi merupakan suatu hal yang kasuistik dalam dunia periklanan Indonesia.

Maka dari itu perlu ada sebuah tanggung jawab dari pelaku usaha periklanan obat mulai dari produsen obat, perusahaan priklanan dan media televisi. Tanggung jawab ini muncul karena adanya hubungan hukum diantara ketiga pihak diatas. Yaitu surat perjanjian kerjasama antara produsen obat dengan perusahaan periklanan untuk pembuatan materi ilan dan jadwal penayangan iklan serta perjanjian perjanjian penayangan iklan obat antara perusahaan periklanan yang mewakili produsen obat dengan media televisi.

Pasal 46 ayat (5) Undang-Undang penyiaran menetapkan bahwa lembaga penyiaran dalam hal ini media televisi harus mempertanggung jawabkan siaran iklan niaga termasuk iklan obat sehingga apabila ada klaim dari korban iklan obat maka pihak media juga ikut bertanggung jawab.

Pasal 20 Undang-undang Perlindungan Konsumen menyebutkan bahwa pelaku usaha periklanan bertanggung jawab atas iklan yang diproduksi dan segala akibat yang ditimulkan oleh iklan tersebut. Yang dimaskud dengan pelaku usaha periklanan dalam pasal ini adalah produsen, perusahaan periklanan, dan media.

Dengan demikian dasar pengenaan tanggung jawab terhadap produsen, perusahaan dan media televisi secara tanggung renteng atas tayangan iklan obatnya yang merugikan konsumen adalah surat perjanjian kerjasama antara produsen obat, perusahaan periklanan dan media televisi yang telah menetapkan tanggung jawab masing-masing pihak dan ketentuan tayangan iklan obat yang meliputi Etika Pariwara Indonesia, Undang-Undang Penyiaran dan Undang_undang Perlindungan Konsumen.

Dalam Etika Pariwara Indonesia atau yang biasa disebut dengan Tata Krama dan Tata Cara Periklanan Indonesia pada Bab IV point E dijelaskan tentang sanksi terhadap setiap pelanggaran Etika Pariwara Indonesia yaitu sebagai berikut:

1. Bentuk sanksi terhadap pelanggaran memiliki bobot dan tahapan, yaitu peringatan hingga dua kali kemudian penghentian penyiaran, dimana untuk setiap tahapan diberi rentang waktu

2. Penyampaian sanksi dilakukan secara tertulis dengan mencantumkan jenis pelanggaran dan rujukan yang digunakan secara tertulis dengan mencantumkan jenis pelanggaran dan rujukan yang digunakan.

3. Distribusi penyampaian sanksi pada setiap bobot atau tahap pelanggaran adalah sebagai berikut:

- Peringatan Pelanggaran; kepada pihak pelanggar dan asosiasi atau lembaga terkait.

- Perintah Penghentian Penyiaran; kepada semua pihak yang terlibat, asosiasi atau lembaga terkait, serta media yang bersangkutan.

Untuk pelanggaran yang dilakukan Produsen, khusus dalam hal penggunaan tenaga dokter dalam iklan obat yang melanggar pasal 17 ayat (1) Point f yang melarang pelaku usaha periklanan melanggar etika dan/atau ketentuan peraturan perundang-undangan mengenai periklanan, juga Pasal 62 Ayat (2) Undang-Undang Perlidungan Konsumen yang menyatakan bahwa pelaku usaha yang melanggar 
ketentuan sebagimana dimaksud dalam Pasal 11, Pasal 12, Pasal 13 Ayat (1), Pasal 14, dan Pasal 17 Ayat (1) huruf D dan Huruf F dipidana dengan pidana penjara paling lama 2 (dua) tahun atau pidana denda paling banyak Rp500.000.000,00 (lima ratus juta Rupiah)

Sedangkan orang yang berpura-pura jadi dokter dalam iklan obat atau aktor yang menjadi dokter dalam iklan obat, hal tersebut merupakan pelanggaran terhadap Pasal 73 point 1(satu) Undang-Undang No 29 Tahun 2004 tentang Praktik Kedokteran yang berbunyi "Setiap orang dilarang menggunakan identitas berupa gelar atau bentuk lain yang menimbulkan kesan bagi masyarakat seolah-olah yang bersangkutan adalah dokter atau dokter gigi yang telah gigi yang telah memiliki surat tanda registrasi dan/atau surat izin praktek". Untuk pelanggaran pasal ini maka Undang-Undang ini juga mengatur tentang ketentuan pidana pada pasal 77 disebutkan bahwa "setiap orang yang dengan sengaja menggunakan identitas berupa gelar atau bentuk lain yang menimbulkan kesan bagi masyarakat seolah-olah yang bersangkutan adalah dokter atau dokter gigi yang telah memiliki surat tanda registrasi dokter atau surat tanda registrasi dokter gigi dan/atau surat izin praktik sebagaimana dimaksud dalam Pasal 73 ayat (1) dipidana dengan pidana penjara paling lama 5 (lima) tahun atau denda paling banyak Rp 150.000.000,00 (seratus lima puluh juta rupiah). Ketentuan pidana ini dapat dijatuhkan tentunya jika unsur pidana dalam pasal ini terpenuhi yaitu; adanya perbuatan seseorang yang dengan sengaja menggunakan identitas berupa gelar atau bentuk lain yang menimbulkan kesan bagi masyarakat seolah-olah yang bersangkutan adalah dokter atau dokter gigi yang telah memiliki surat tanda registrasi dokter atau surat tanda registrasi dokter gigi dan atau surat izin praktik.

Untuk iklan obat di televisi yang diperankan oleh dokter sungguhan hal tersebut dapat merupakan pelanggaran terhadap. Kode Etik Kedoteran. Pada bagian kewajiban umum, Pasal 3 KODEKI (Kode Etik Kedokteran) disebutkan, dalam melakukan perkerjaan kedokterannya, seorang dokter tidak boleh dipengaruhi, oleh sesuatu yang mengakibatkan hilangnya kebebasan dan kemandirian profesi. Pada penjelasan Pasal 3 Kode etik Kedokteran disebutkan, perbuatan berikut dipandang bertentangan dengan etika yaitu membuat ikatan atau menerima imbalan dari perusahaan farmasi/obat, perusahaan alat kesehatan/kedokteran atau badan lain yang dapat mempengaruhi pekerjaan dokter; melibatkan diri secara langsung atau tidak langsung untuk mempromosikan obat, alat atau bahan lain guna kepentingan dan keuntungan pribadi dokter.

\section{PENUTUP}

Penggunaan tenaga kesehatan seperti dokter maupun aktor yang menyerupai seorang dokter dalam iklan yang biasa kita lihat di televisi adalah bentuk pelanggaran khususnya pelanggaran terhadap Etika Pariwara Indonesia dan SK Menkes No. 368 tentang Pedoman obat bebas, obat tradisionil, kosmetika dan perbekalan rumah tangga, yang lain mengatakan bahwa iklan tidak boleh menggambarkan atau menimbulkan kesan pemberian anjuran, rekomendasi, atau keterangan tentang 
penggunaan obat tertentu oleh profesi kesehatan seperti dokter, perawat, farmasis, laboratoris, dan pihak-pihak yang mewakili profesi kesehatan, beserta segala atribut, maupun yang berkonotasi profesi kesehatan. Tanggung jawab terhadap pelanggaran tersebut merupakan tanggung jawab dari setiap pihak yang terlibat dalam iklan tersebut, mulai dari produsen, perusahaan periklanan maupun model iklan maupun aktor iklan .

Oleh karena itu perlu adanya aturan baku dalam bentuk undang- undang periklanan yang wajib ditaati oleh seluruh pihak yang terlibat dalam periklanan, serta sosialisasi tentang peraturan perundangan yang berkaitan dengan periklanan dan perlindungan konsumen. Agar semua pihak mengetahuinya. Disamping perlunya pelaksanaan penegakan hukumnya sehingga peraturan tidak hanya sekedar peraturan tetapi sesuai dengan tujuan pembuatan peraturan itu sendiri seperti perlindungan bagi pihak yang dirugikan.

\section{DAFTAR PUSTAKA}

Aziz, N. (2019). Pengaruh Strategi Promosi Terhadap Keputusan Pembelian Yang Dimediasi Oleh Minat Beli Pada Konsumen Restoran KFC Cabang Khatib Sulaiman Padang. https://doi.org/10.17605/OSF.IO/V92TS

Aziz, N. (2019). Analisis Pengaruh Kualitas Produk, Harga, Promosi Terhadap Keputusan Pembelian Air Minum Dalam Kemasan (AMDK) Merek Aicos $\begin{array}{lllll}\text { Produksi } & \text { Pt. } & \text { Bumi } & \text { Sarimas }\end{array}$ https://doi.org/10.17605/OSF.IO/8XKYB

Bambang Sunggono, Metodologi Penelitian Hukum, PT. Raja Grafindo Persada, Jakarta, 1998.

F., \& Afriyeni, A. (2019). Aktivitas Pemasaran Produk Tabungan Pada PT. Bank Pembangunan Daerah (BPD) Sumatera Barat Cabang Utama Padang. https://doi.org/10.31219/osf.io/tf2bz

Hanifah yusuf dan Amri amir.Etika Kedokteran dan hukum kesehatan. EGC. Jakarta. 1999.

Hidayati, R. R., \& Marlius, D. (2018). Aktivitas Promosi Dalam Meningkatkan Dana Pihak Ketiga Pada PT. Bank Perkreditan Rakyat (BPR) Batang Kapas Pesisir Selatan. https://doi.org/10.31227/osf.io/8dgqn

Jamarnis, S., \& Susanti, F. (2019). Pengaruh Harga Dan Periklanan Melalui Internet Terhadap Keputusan Pembelian Produk Sabun Merek Lux Pada Mahasiswa STIE “KBP” Padang. https://doi.org/10.31227/osf.io/xz3d8 
Jaya, R. S., \& Susanti, F. (2019). Pegaruh Integrated Marketing Communication Terhadap Brand Equity Pada Mc Donalds A.Yani Padang. https://doi.org/10.31227/osf.io/4ebk2

Marlius, D. (2016). Pengaruh Bauran Pemasaran Jasa Terhadap Minat Nasabah Dalam Menabung Pada Bank Nagari Cabang Muaralabuh. https://doi.org/10.31227/osf.io/vdqgx

Mayliza, R. (2019). Pengaruh Citra Perusahaan (Corporate Image) Dan Penanganan Keluhan (Complaint Handling) Terhadap Loyalitas Pelanggan (Loyality) Natasha Skin Care Di Kota Padang. https://doi.org/10.17605/OSF.IO/DF9XJ

Mayliza, R. (2019). Pengaruh Kesadaran Merek, Asosiasi Merek Dan Perception Of Quality Terhadap Keputusan Pembelian Hospital Bed Merek Paramout Di PT. Aga Medika Utama Padang (Studi Kasus Rumah Sakit Umum Kota Padang). https://doi.org/10.17605/OSF.IO/VYQ4E

Munir Fuady, Sumpah Hippocrates ( Aspek hukum Malpraktek Dokter), PT. Citra aditya Bakti. Bandung 2005.

Rhenald Kasali, Managemen periklanan Konsep dan Aplikasinya Di Indonesia, Pustaka Utama Graviti, 1995, Jakarta.

Soerjono Soekanto, Penghantar Penelitian Hukum, UI Press, Jakarta 1986

Sumartono. Terperangkap Dalam Iklan, Alfabeta, Bandung 2002.

Shidarta. Hukum Perlindungan Konsumen Indonesia. Grasindo. Jakarta 2004.

Susanti, F. (2014). Pengaruh Tarif Iklan Terhadap Pendapatan Pada PT. Radio Swara Carano Batirai Indah Batusangkar. https://doi.org/10.31227/osf.io/dy863

Tufik H Simatupang, Aspek Hukum Periklanan Dalam Perspektif Perlindungan Konsumen, PT. Citra AdityaBakti, Bandung 2004. 